\title{
A Bibliography on Standards for Evaluating Libraries
}

T HIS BIBLIOGRAPHY OF 138 references is the result of a search of the literature for informative statements which might be helpful in determining guidelines for the evaluation of subject collections in federal government libraries. It was compiled as Part II of "A Critique on Standards for Evaluating Library Collections" which was prepared for members of the Federal Library Committee's Task Force on Acquisition of Library Materials and Correlation of Federal Library Resources.

Much has been written on standards but there is less in the nature of significant facts based on actual experience in developing and applying criteria. Accordingly, the references included are only those which have been selected because of their contribution to (1) an understanding of the elements of library standards and criteria necessary for subject evaluation, and (2) methodology suitable for application to the evaluation task. A few references were not available for examination.

The arrangement is alphabetical by author, and each entry includes a descriptive annotation or an abstract from the contents of the article or book cited in order to call attention to a significant portion of it.

Miss Ottersen is Research Bibliographer, Biological Sciences Communication Project, The George Washington University Medical Center. This study was supported by OE Contract no. OEC-0-8080310-3742 (095).

\section{A Bibliography ON Standards For Evaluating Libraries}

Adams, Velma Lee. "Growth of a Library," Arkansas Libraries 12:7-9 (October 1955).

In seeking accreditation by the North Central Association, Southern State College, Magnolia, Arkansas, made a study of the library and its collection. Faculty experts made recommendations for additions and discards, and library holdings were compared with appropriate lists.

Adelman, George. "Ask the Men Who Know; the Neurosciences Research Program Goes to the Best People in the Field and Asks Them," Library Journal 94:1413-15 (1 April 1969).

Specialists in the neurosciences will have to be consulted in their field since the literature is too great for a librarian to cope with.

American Library Association. Standards for College Libraries. Chicago, Ill., American Library Association, 1959.

American Library Association. Public Libraries Division. Coordinating Committee on Revision of Public Library Standards. Public Library Service-A Guide to Evaluation with Minimum Standards. Chicago, American Library Association, 1954.

Specific standards, defining minimum adequacy rather than goals, are based on best professional opinion checked by statistical study where needed and possible. Among standards applicable to collections are: (1) Library program is focused upon clear and specific objectives; (2) materials are selected, retained, and discarded in 
light of conscious objectives and written policy statement covers selection, maintenance of material; (3) systematic removal of nonuseful material.

Asheim, Lester, and others. The Humanities and the Library; Problems in the Interpretation, Evaluation and Use of Library Materials. Chicago, American Library Association, 1957. 304p.

A textbook about the contents of books and the criteria for evaluating them.

Association of College and Research Libraries. Quantitative Criteria for Adequacy of Academic Library Collections. Chicago, American Library Association, 1965. 12p.

Association of College and Research Libraries. Committee on Liaison with Accrediting Agencies. "Guide to Methods of Library Evaluation," College and Research Libraries News 9:293-99 (October 1968).

The following evaluation methods are offered as aids in judging the adequacy of an academic library: use of selected lists, consultation with specialists, and sampling of students about ease in obtaining sources. The coverage must be adequate for courses offered and research in progress.

Association of College and Research Libraries. Committee on Standards. "Standards for College Libraries," College and Research Libraries 20:274-83 (July 1959).

Ibid., Drexel Library Quarterly 2:25163 (July 1966).

A summary of the standards for the book and periodical collection follows: (1) The collection should meet full curriculum needs of the undergraduate and graduate and support faculty in keeping abreast of advances, or for independent study; (2) the collection should contain "standard works which represent the heritage of civilization"; (3) there should be a strong and up-to-date reference collection in all major fields of knowledge-and not restricted to curriculum; (4) periodical collections should meet requirements of collateral reading of undergraduates and in some measure meet research needs of advanced students and faculty; (5) "Printed manuscript, and archival materials pertaining to the institutions of which the library is a part should be collected and preserved"; (6) no censorship of librarian's selection on all sides of a controversial issue; (7) quality of collection should not be sacrificed to unnecessary duplication; (8) obsolete materials should be weeded with advice from faculty members; (9) library holdings should be checked frequently against standard bibliographies; (10) the size is determined by an analysis of college statistics-curriculum, number of students, faculty, etc.

Association of College and Research Libraries. Standards Committee. College and University Library Accreditation Standards-1957; comp. by Eli M. Oboler and others. Chicago: American Library Association, 1958. 46p. (ACRL Monograph No. 20).

"This monograph is the first publication in one place of all the requirements for libraries and institutions of higher education specified by the twenty-one professional and six regional accrediting associations recognized by the National Commission on Accrediting."

Bach, Harry. "Evaluation of the University Library Collection," Library Resources \& Technical Services 2:24-29 (Winter 1958).

The two methods most commonly employed to appraise the adequacy of an academic library are faculty opinion and bibliographic checking. Comparison with other institutions, availability checks, and sampling techniques are other procedures. There is a useful bibliography.

Bailey, George M. "The Role of the Standards," Drexel Library Quarterly 2:20712 (July 1966).

A general paper on the "Standards for College Libraries."

Blanchard, J. Richard. "Planning the Conversion of a College to a University Library," College \& Research Libraries 29:297-302 (July 1968).

Abstract: "Many new university librar- 
ies are being rapidly developed out of older, small college collections. Methods and standards available for the planning of such libraries include the Clapp-Jordan formula for book collections and standards for buildings and book collections used by the State of California. Professor Robert Hayes of the School of Library Service, UCLA, is preparing a formula for the development of collections in University of California libraries. Methods used in planning for the development of the University of California Library, Davis, are described."

Bloomquist, Harold. "The Status and Needs of Medical Libraries in the United States," Journal of Medical Education 38:145-63 (March 1963).

No standards for medical libraries have been developed but three medical librarians, Rogers, Esterquist, and Meyerhoff, suggest collections of 100,000 volumes.

Brown, Helen M. "The Standards and the College Library in 1965," Drexel Library Quarterly 2:202-06 (July 1966).

The mushrooming of college enrollment indicates that some changes in the "Standards" may be required. The author quotes the following: "Emery M. Foster, Consultant for the Library Services Division of the United States Office of Education, has recently presented to the ACRL Standards Committee a proposal to analyze the Standards by using the statistics now available at USOE.

"In order to reflect quality in the quantity standards, the analysis must include only the statistical characteristics of generally acknowledged good institutions known to have good library services. If the standards can be statistically shown to be the practice of publicly recognized quality libraries, it will be accepted as a valid standard for that type and size of institution."

Buck, Paul Herman. Libraries and Universities, Addresses and Reports; edited by Edwin E. Williams. Cambridge, Mass.: Harvard University Press, 1964. 172p.

“. . . The value of Harvard's great collection can be ascribed in large part to the fact that it has been built up to serve scholars; much of it, indeed has been selected by members of the Faculties. ... Selection of books for a library like this calls for an attempt to foresee the future courses of research and to obtain publications that, though they seem insignificant today, will be wanted by scholars tomorrow. The richness of Harvard's holdings is a product of the joint effort of professors and librarians over many generations, and no other library today has the assistance of a community equally well qualified to help build it for the future."

Burdick, Charles. "Library and the Academic Community," Library Resources of Technical Services 8:157-60 (Spring 1964).

"In recent years the entire concept of a library's collection has changed from quantity to quality. While a library containing several million volumes has unquestioned merit, its mere size is not positive proof of competence. With care and proper selection, a library can build a superb collection in a given study area. The Hoover Institution at Stanford University with fewer than 200,000 volumes, ranks as a world leader in its fields of endeavor. No longer need a library hide its collective head because of the limited number of books on its shelves."

Burns, Norman. "Accrediting Procedures with Special Reference to Libraries," College \& Research Libraries 10:155-58 (April 1949).

The author writes: "It is clear, then, that in appraising the worth of an institution it is essential that one begin with the purposes of the institution and proceed from there to examine its program-the curriculum, the faculty, the student, personnel services, the library-in the light of the particular goals which the institution has set for itself. Implicit in this approach is the concept of a qualitative approach rather than reliance on merely quantitative measures."

Burns, R. W. Evaluation of the Holdings in Science/Technology in the University of Idaho Library. Moscow: Universi- 
ty of Idaho Library, 1968. 52p. Mimeographed.

Among the criteria against which the library was measured were lists of materials published by professional societies, basic lists in various disciplines, holdings of other libraries, availability of indexing and abstracting services, and serials covered therein.

Carnovsky, Leon. "Evaluation of Library Services," UNESCO Bulletin for Libraries 13:221-25 (October 1959).

In evaluating a collection attention should be paid not merely to the size but to the quality and relation to the purpose of the library.

Carnovsky, Leon. "Measurement of Public Library Book Collections," Library Trends 1:462-70 (April 1953).

The quality of the book collection can be tested by checking against booklists or bibliographies.

Carnovsky, Leon. "Public Library Surveys and Evaluation," Library Quarterly 25 (1) :23-36 (January 1955).

ALA's Post-War Standards for Public Libraries (1943) states: "Only to a limited and somewhat mechanical extent can the result of the intricate process of book selection in terms of an actual collection of books be measured by any system of standards." Appraisals can be made by quantitative measures (numbers of books and their distribution by subject or type, or by sample checks against lists of titles-or bibliographies. Although the checklist method is time-consuming the author considers it more desirable than a report on numbers.

Carnovsky, Leon. "Self-evaluation; or How Good Is My Library?," College \& Research Libraries 3:304-10 (September 1942).

The author says " . . a college library is good or not in the degree to which it is equipped to aid in achieving the aims of the college." Many accrediting agencies arbitrarily define the book content of the library. Lists such as Shaw's and Mohrhardt's are comprehensive for colleges and junior colleges but become obsolete quickly.

Carnovsky, Leon. "Standards for Special Libraries; Possibilities and Limitations," Library Quarterly 29:168-73 (July 1959).

By the very nature of the "special" library it is difficult to assign standards. Being special, or unique, one can but ask the question as to whether the library supplies the information required by the parent institution.

Carter, Mary D. and Bonk, W. J. Building Library Collections. N.Y., Scarecrow Press, 1964, 2d ed. 287p.

The three important factors in evaluating a collection are (1) what kinds of books are in the collection and how valuable each is in relation to other books on the subject which are not in the library; (2) are the books in the collection appropriate for the community to be served regardless of how valuable the books may be in an abstract evaluation of their worth; and (3) what are the purposes which this particular collection is supposed to accomplish?

Chicorel, Marietta. "Statistics and Standards for College and University Libraries," College \& Research Libraries 27: 19-22, 51 (January 1966).

Standards for college library book collections are based on the numbers of students and the numbers of courses given and the amount and kind of research being performed. That there are no standards for university libraries "may be in part due to the fact minimum standards may be interpreted to be maximum standards, and that increases due to population and knowledge explosions cannot be built in." In university libraries the strength of library services is not indicated by numbers of books.

Clapp, Verner W. and Jordan, R. T. "Quantitative Criteria for Adequacy of Academic Library Collections," College \& Research Libraries 26:371-80 (September 1965).

—. "Corrigenda, College \& Research Libraries 27:72 (January 1966).

New formulas are developed for estimat- 
ing the number of volumes required for minimum adequacy by academic libraries of widely differing characteristics.

Coale, Robert P. "Evaluation of a Research Library Collection: Latin-American Colonial History at the Newberry," Library Quarterly 35:173-84 (July 1965).

“ . . . bibliographic checking seems to be most feasible way to evaluate its holdings. ..."

Community Studies, Inc. Libraries in Metropolis; a Study of Public Library Services in the Kansas City and St. Louis Metropolitan Areas. Kansas City, Community Studies, Inc., 1966.

The Enoch Pratt Free Library list was used in sampling the quality of the reference collections.

Cooper, Marianne. "Criteria for Weeding of Collections," Library Resources \& Technical Services 12:339-51 (Summer 1968).

Criteria for weeding and storage were determined based on age and usage. They were related to goals, resources, organization, and administration of the library.

Covey, Alan Dale. "Evaluation of College Libraries for Accreditation Purposes," Dissertation Abstracts 15(10):1863 (1955).

“. . . Library literature was surveyed for criteria, and Schedule C was tested at a number of accredited California teacher's colleges. Among conclusions presented are the following: an institution should be appraised in terms of its success in achieving its own stated objectives and in relation to its social patterns as an agency of higher education; a combination of quantitative and qualitative criteria is necessary, but quantitative are to be used only as discussion points rather than as fixed minimal standards; the ALA service load formula appears to be the most satisfactory quantitative Standard; and the quality of a library staff is indicated by its status within the college." Thesis for Ed.D., Stanford University, 1955.

Danton, J. Periam. "The Selection of Books for College Libraries: An Examination of Certain Factors Which Affect Excellence of Selection," Ph.D. thesis, University of Chicago, 1935.

"Attempts to determine effect of librarians, faculty, and book fund policies on quality of book selection for liberal arts college libraries. Charles B. Shaw's A List of Books for College Libraries was used as basis for formulation of a book-collection quality index ...." (quoted from Cohen's Library Science Dissertations).

Danton, J. Periam. "The Subject Specialist in National and University Libraries, with Special Reference to Book Selection," Libri 17(1):42-58 (1967).

"Of the world's numerous kinds of libraries, the national and the university may be properly characterized as having responsibilities for both general and universal or nearly universal collecting in the realm of scholarship. That is, these two, and only these two, commonly collect over a very broad spectrum, and in depth, material which makes possible the creation of new knowledge. ..."

Quality of selection is the truest test of the value of a collection.

Downs, R. B. "Doctoral Degrees and Library Resources," College \& Research Libraries 30:417-21 (September 1969).

This paper updates a similar report published in 1966 showing the relationship between library holdings and the number of doctoral degrees granted in several American universities.

Downs, Robert B. "Doctoral Programs and Library Resources," College \& Research Libraries 27:123-29, 141 (March 1966).

"The chief purpose of the present investigation is to determine whether there exists any direct correlation between the number and variety of doctoral degrees awarded and the strength of library resources in individual institutions." The author states that high-level doctoral work in a variety of fields requires 500,000 volumes. An institution outstanding for its graduate offerings is almost invariably equally notable for the strength of its library resources. 
Downs, Robert B. "Research in Problems of Resources," Library Trends 6:147-59 (October 1957).

"Techniques for describing and evaluating library facilities on the research level are still experimental. No generally accepted standards have been accepted." Some advocate a specialist's point of view, some the librarian's broader view of library's total resources. Should surveys be restricted to a narrow subject? Quantitative or qualitative?

Downs, Robert B. and Heussman, John W. "Standards for University Libraries," College \& Research Libraries 31:28-35 (January 1970).

The Committee on University Library Standards of the Association of College and Research Libraries and the Association of Research Libraries, in an attempt to formulate standards chose fifty U.S. and Canadian institutions as a control group for study. The tables presented here concerned with the book collection are: (1) Relationships of Total Library Expenditures to Salaries and Wages; Books, Periodicals, and Binding; General Expenses, (2) Student Per Capita Expenditures for Books, Periodicals, and Binding, and for Total Library Expenditures, (3) Resources: Volumes Added, Current Periodicals, and Microforms, (4) Relationship of Enrollment to Number of Volumes and to Number of Current Journals.

Downs, Robert B. "Uniform Statistics for Library Holdings," Library Quarterly 16: 63-69 (January 1946).

Several possible methods for measuring holdings are described. Reporting bibliographical units rather than accessioned volumes is recommended. Linear measurement has its adherents but a report of bulk gives no idea of numbers of volumes.

Eells, Walter C. "Measurement of the Adequacy of a Secondary School Library: A Report on One Phase of the Co-Operative Study of Secondary School Standards," ALA Bulletin 32:160 (March 1938).

"Other factors being equal, a library which has the largest percentage of recent- ly published titles in certain fields is probably superior to one with only a small percentage of recent titles. ..."

Eells, Walter C. "Recency as a Measure of Book Collection," Junior College Journal 8:308-10 (March 1938).

An analysis of recency in Mohrhardt's A List of Books for Junior College Libraries (1937).

Emerson, W. L. "Adequacy of Engineering Resources for Doctoral Research in a University Library," College \& $R e$ search Libraries 18(6):455-60, 504 (1957).

A study of the literature cited in dissertations of doctoral candidates in engineering at Columbia University to determine whether the university libraries could supply these sources.

Falk, Leslie K. and Lazerow, Samuel. "Comprehensive Collecting-Then and Now," Medical Library Association, Bulletin 49: 432-42 (July 1961).

What is meant by "comprehensive" collection? It should acquire a copy of every procurable "publication" in (a) core subject areas, (b) immediately supporting disciplines, (c) nonstandard as well as standard explanations, (d) publications written for laymen as well as practitioners, and (e) value criteria should not intrude.

Why collect comprehensively? (a) "If one library collects and preserves fully in a well-defined field, other libraries, regardless of size, can accordingly adjust their collecting and withdrawal activities. (b) The indexing and cataloging of medical literature is most effectively accomplished by one institution having the literature closely under its control. (c) Comprehensive collecting is a requirement for the preservation of the history of civilization."

Frodin, Reuben. "Finance and the College Library," Library Quarterly 24:374-81 (October 1954).

The kind of educational institution determines the character of the library. The author lists about twenty kinds of material which should be in a college library and suggests per capita expenditures. 
Fussler, Herman H. "Acquisition Policy; Larger University Library," College \& Research Libraries 14:363-67 (October 1953).

Enlarging upon his theory that a research collection often has books for which there are no current specific needs, the author says: “. . . most of the books in a large research library are subjected to an extremely low, almost negligible amount of use. The use of a large research library is clearly concentrated at any one point in time over a small percentage of its total holdings. It is, of course, the balance of the library's holdings which are so infrequently used that in part distinguishes a research library from a college or reference library...."

Fussler, Herman H. and Simon, J. L. Patterns in the Use of Books in Large Research Libraries. Chicago, University of Chicago Press, 1969. 210p.

Suggest devising formulas in terms of a variety of predictor variables relative to use, e.g., Subject + Time elapsed since last use + Language.

Gelfand, Morris A. “A Historical Study of the Evaluation of Libraries in Higher Institutions by the Middle States Association of Colleges and Secondary Schools," Ph.D. thesis, New York University, 1960.

"Chiefly accreditation policies but analysis practices and results of library evaluations undertaken by A.L.A. after 1946."

Gelfand, Morris A. "Techniques of Library Evaluation in the Middle States Association," College \& Research Libraries 19:305-20 (July 1958).

Chiefly quotes from Middle States Association of Colleges and Secondary Schools, Commission on Institutions of Higher Education.

"The Get-'Em-All Theory of Book Buying," Library Journal 85:3387-93 (October 1960).

Views of six librarians on "bloc-buying" and "get-'em-all" theory. The consensus is that the professional responsibility of a librarian is in book selection.
Gormley, Mark M. Academic Libraries, in Maurice M. Tauber and Irlene R. Stephens, eds., Library Surveys, p.169-79 New York: Columbia University Press, 1967.

"It is true that a small liberal arts college could admirably serve its purpose if it has a large percentage of the items listed in the Shaw, Lamont, and Michigan lists, a generous input from such a current aid as Choice, and additional items to satisfy unique demands. ...." Development of a university library requires more comprehensive study of many subject fields.

Gosnell, Charles F. “The Rate of Obsolescence in College Library Book Collections as Determined by an Analysis of Three Select Lists of Books for College Libraries," Ph.D. thesis, New York University, 1943.

Information was derived from a literature review and an analysis of Mohrhardt's, A List of Books for Junior College Libraries, 1937, and the 1931 and 1940 editions of Shaw's, A List of Books for College Libraries.

Gosnell, Charles F. "Systematic Weeding," College \& Research Libraries 11:137-38 (April 1950).

The author gives the following reasons for weeding: (1) the size of the library should depend on the objectives of the library and the demands of it; (2) there is a definite relationship between the age of the book and the likelihood that it will be used.

Gosnell, Charles F. "Values and Dangers of Standard Book and Periodical Lists for College Libraries," College \& Research Libraries 2:216-20 (June 1941).

Chiefly a study of the Shaw, Mohrhardt, and Shaw Supplement lists, and obsolescence and mortality of such lists.

Harley, J. "Quality Versus Quantity," Library Review 109:284-86 (Spring 1954).

A somewhat amusing article on book selection-on understanding of what constitutes value and the ability to recognize it. The author thinks there are few librar- 
ies which would not profit by a little "spring cleaning."

Harlow, Neal. "Levels of Need for Library Service in Academic Institutions," College \& Research Libraries 24:359-64 (September 1963).

"It is the hypothesis of this paper that there are distinctive levels of academic and research need in respect to library service within institutions of college and university rank, and if this be true, individual library programs can be designed to satisfy them...."

The depth of these library collections varies with need.

Haro, R. P. "Some Problems in the Conversion of a College to a University Library," College \& Research Libraries 30:260-64 (May 1969).

Instead of conforming to purely statistical considerations concerning size of enrollment or research and teaching programs the author makes a plea for quality of library materials and a need for selectivity.

No one list or combination of lists can be safely used as a purchasing guide without the talents of a subject specialist or subject bibliographer.

Hart, James D. "Search and Research: The Librarian and the Scholar," College \& Research Libraries 19:365-74 (September 1958).

Referring to the learned academic scholar he says; "Such a scholar must have an enormous accumulation of books, journals, and all the ancillary materials of a great library. This is the stuff of his research. Here is contained the expression of man's intellectual history. The scholar needs not only what Matthew Arnold called 'The best that has been known and said,' but the commonplace as well, for the mediocre is often quite as valuable as the great in providing an understanding of the climate of opinion out of which grew-or against which rebelled-a Milton, a Moliere, or a Goethe. For this reason, 'a man will,' as Dr. Johnson said, 'turn over half a library to make one book. ..."”

Hawkins, Miriam. "Questionable Medical Literature and the Library: A Symposi- um. The National Library of Medicine," Medical Library Association. Bulletin 51: 475-79 (October 1963).

Since National Library of Medicine's policy is to collect comprehensively it does collect such material.

Hirsch, Felix E. "How Good Are Our College Libraries?," New Jersey Education Association Review 32:442-43 (June 1959).

A general article. College library standards say the library should be "the most important intellectual resource of the academic community."

Hirsch, Felix E. "New College Library Standards," Library Journal 84:1994-96 (15 June 1959).

The new standards aim to overcome the traditional variations in type of collegepublic, private, denominational, etc.-and in regional differences in excellence. "The standards are more concerned with excellence and instructional usefulness of the holdings than with numbers. ..."

Hirsch, Felix E. "New Standards to Strengthen College Libraries," ALA Bulletin 53:679-82 (September 1959).

Important features of the standards for book collections are: (1) "Any attempt at censorship from whatever sources or for whatever reasons must be resisted; (2) First among the factors affecting the size of the collections and the rate of growth are the nature of the curriculum, number of courses, methods of instruction, and number and character of graduate programs. The size of the student body is the fourth important point to consider; (3) . . . The Standards for College Libraries emphasize the role which outstanding recent subject bibliographies and authoritative general lists should play in ascertaining the high caliber of book holdings and periodical subscriptions."

Hirsch, Felix E., ed. "Raising the Standards: College Libraries," Drexel $\mathrm{Li}$ brary Quarterly 2:199-291 (July 1966).

A collection of papers. Partial contents: Hirsch, F. E.- "What Is Past Is Prologue"; Brown, H. M.- "The Standards and the 
College Library in 1965"; Bailey, G. M."The Role of the Standards"; Meder, A. E. - "Accrediting Agencies and the Standards"; McComb, R. W.- "The Problems of Extension Centers"; Tanis, N. W. and Jacobs, K. J.- "Strengthening the College Library."

Hirsch, Felix E. "What Is Past Is Prologue," Drexel Library Quarterly 2(3): 199-201 (July 1966).

Chiefly an introduction to a discussion of the "Standards for College Libraries" and "Standards for Junior College Libraries."

Hirsch, Rudolph. "Evaluation of Book Collections," in Wayne S. Yenawine, $\mathrm{Li}$ brary Evaluation, p.7-20, Syracuse, N.Y., Syracuse University, 1959.

Four methods of evaluating a library collection are described: (1) by librarians, scholars, or laymen in terms of library's policies and purposes; (2) by checking against standard or specially compiled lists; (3) by data on use; and (4) by comparison of expenditures against other institutions.

Hodgson, James G. The Literature of $\mathrm{Li}$ brary Standards. Third Military Librarians' Workshop. Monterey, Calif., U.S. Navy Postgraduate School, 1959. (AD 479447).

Discusses the development of library standards. A basic criterion is whether the library is adequate for its purpose. The bookstock is adequate only when it fills user needs in the most economical manner, considering costs to user and to library. A formula is provided which indicates when too large a proportion of material is borrowed from other libraries which it would have been cheaper to own.

Holley, Edward C. and Hendricks, Donald D. Resources of Texas Libraries. Austin, Texas State Library, 1968. 352p.

Includes lists of 100 basic books and 257 basic reference books used to check holdings in the various libraries.

Humphreys, K. W. "National Library Functions," UNESCO Bulletin for $\mathrm{Li}$ - braries 20:158-69 (July-August 1966).

Includes some discussion of the depth of national library collections.

Hurt, Peyton. "Principles and Standards for Surveying a College Library," College \& Research Libraries 2:110-16 (March 1941).

The purpose of a survey is to study the performance of the library as an integral part of the whole college. It is aided by standard bibliographical aids provided by experts and accrediting agencies.

International Federation of Library Associations. Libraries of the World: A Longterm Programme for the International Federation of Library Associations. The Hague, Nijhoff, 1963. 62p.

Because of the avalanche of literature it is impossible to pursue the ideal of completeness. Even national libraries, after meeting their national obligations, have to satisfy themselves with a selection from scholarly works published abroad.

Jenkins, Frances B. "The Acquisition of Scientific and Technological Material," Library Trends 3:414-22 (April 1955).

"The development of a library acquisitions program which will ensure a collection of materials in the field of science and technology adequate to meet the demands placed upon a library depends basically on the answer to such questions as: Who will use the collection? What materials are necessary to provide good service to these users? How can the materials be made available? . . . Complete sets of all the serials which are of potential value to the users constitute the ideal resources of the library; incomplete files of periodicals are almost valueless for the particular issue needed is not usually available."

Johnson, Robert K. "Resources of Selected Military Libraries," Library Quarterly 32:40-50 (January 1962).

Eighteen military libraries are surveyed. Author says these should not be compared with large civilian colleges and universities. “. . . The importance of a library collection depends on other factors as well as 
size. The distinction of important military libraries lies in their subject specialization more than in the number of items collected."

Jones, F. Taylor. "The Regional Accrediting Association and the Standard for College Libraries," College \& Research $\mathrm{Li}$ braries 22:271-74 (July 1961).

A discussion of quantitative standards vs qualitative and how ALA Standards will be implemented by the regional association.

In the modern concept of accreditation there are three fundamental questions: (1) Are this institution's objectives clearly defined, appropriate, and controlling in its development?; (2) has it established the conditions under which it can achieve its objectives?; (3) is it in fact achieving them?

Kebabian, Paul B. "The Distance to a Star: Subject Measurement of the Library of Congress and University of Florida Collections," College \& Research Libraries 27:267-70 (July 1969).

LC catalog is used as measurement for Florida collections.

Kraft, Margit. “Argument for Selectivity in the Acquisitions of Materials for Research Libraries," Library Quarterly 37:284-95 (July 1967). "Comment by H. Henneberg," Library Quarterly 38: 286-90 (July 1968).

This author is trying to make a case for selectivity in research libraries and that subject-specialist librarians must be trained. However, much of the paper is devoted to the three arguments generally defended by librarians: (1) The ideal of the research collection is completeness, past, present, and future; (2) The library collects not only for the present but for the future; (3) A research library never becomes obsolete.

Krikelas, James. "Library Statistics and the Measurement of Library Services," ALA Bulletin 60:494-99 (May 1966).

“. . There is no known evidence to demonstrate that size is correlated to quality or service in any way. ..."
Kuhlman, A. F. "Report of the Library Committee; Development of Sound and Practical Criteria for Measuring the Adequacy of the College Library; A Preliminary Statement," Southern Association Quarterly 4:298-302 (May 1940).

Criteria for measuring resources are: (1) A select list of reference books grouped by subjects; (2) a select list of periodicals (Lyle's list); (3) as a measuring rod to book holdings Mohrhardt's, List of Books for Junior College Libraries and Shaw's, Supplement of Books for College Libraries; (4) money spent for books and periodicals during last five years; (5) titles held published during last five years; (6) relation to curriculum.

Kuhlman, A. F. "Two ARL Approaches to Counting Holdings of Research Libraries," College \& Research Libraries 21: 207-11 (May 1960).

Standards for statistics are necessary for an accurate reporting of library holdings. The merits of reporting titles rather than volumes, processed volumes, number of volumes organized and ready for use, or bibliographical items are discussed.

Lane, D. O. "Selection of Academic Library Materials. A Literature Survey," College \& Research Libraries 29:364-72 (September 1968).

"The purpose of this paper is to survey the professional literature as it pertains to the selection of materials for academic libraries, and especially selection with respect to who chooses titles for a collection and the criteria, guidelines, and tools utilized." This pertains to selection policy rather than standards for a collection.

Lazerow, Samuel. "The National Medical Library: Acquisition Program," Medical Library Association, Bulletin 42:447-55 (October 1954).

The subjects collected at Research or Exhaustive level are listed together with NML's definitions of these terms. In surveying the Library, the Survey Committee checked against the Quarterly Cumulative Index Medicus.

Leigh, Robert D. “The Public Library In- 
quiry's Sampling of Library Holdings of Books and Periodicals," Library Quarterly 21:157-72 (July 1951).

“. . . The sample lists of new and standard works, periodicals, government documents, music materials, and films were all made up in such a way as to give some indication of the nature and extent of library holdings of these materials...."

"Library Association Recommends Standards for College Libraries," Library Journal 89:4492 (15 November 1964).

"Basic initial bookstock for a college without degree work, according to the L.A. should be not less than 10,000 titles, and not less than 15,000 titles for a college with degree and specialized advanced courses. The number of periodicals should range from 100 for a small college of further education to a minimum of 600 for a college with substantial advanced work."

Lombardi, John. "Standards at the Grass Roots," ALA Bulletin 60:377-79 (April 1966).

The author is referring to standards developed by the college personnel, a regional accrediting agency, and the American Library Association. Since the paper is addressed to an audience interested in junior colleges, its chief concern is how application of standards affects their accreditation.

Ludington, Flora B. "Evaluating the Adequacy of the Book Collection," College \& Research Libraries 1:305-13 (September 1940).

This is a report of a survey of Mount Holyoke College Library made by the faculty and library staff, not outside experts. In addition to a "common sense" evaluation, the faculty answered questionnaires about adequacy. Selected bibliographies were used for checking together with general lists.

Lyle, Guy R. The Administration of the College Library. 3d ed. New York: Wilson Co., 1961. 419p.

"The adequacy of the college library's collection cannot be measured in quantita- tive terms. ... To judge a collection superior or inferior on the basis of the volume holdings is as absurd as rating a college on the basis of its enrollment."

Lyle, Guy R. "Counting Library Holdings," College \& Research Libraries 11:69-71 (January 1950).

Includes "outline of a method of counting by physical volume."

ARL Committee on the Count of $\mathrm{Li}$ brary Holdings, appointed in January 1948 , recommended its preference for the physical count rather than physical volume. "Since the rates between the number of physical volumes and the number of titles in a library is to some extent indicative of the research character of a library, The Committee recommended that university and large research libraries should also keep a count of acquisition by title."

McComb, Ralph W. "The Problems of Extension Centers," Drexel Library Quarterly 2:220-23 (July 1966).

Standards for Junior Colleges are applicable but development for the specific objective of the center is the aim.

McCrum, Blanche P. "Book Selection in Relation to the Optimum Size of a College Library," College \& Research Libraries 11:138-42 (April 1950).

The author concludes her paper with these words: "Let us use with care criteria derived from frequency of circulation, recency of publication, and a bright new look." The selection of the best books rather than "total coverage, inclusive listings and nondiscriminating completeness" are advocated.

McCrum, Blanche P. "A College Library Makes Its Own Survey Plan,” ALA Bulletin 31:947-52 (1937).

The plan included a questionnaire for faculty use for estimating adequacy of the collection, and checking against Shaw's $A$ List of Books for College Libraries, Lyle's and Litchfield's periodical lists, Mudge, Publishers' Weekly, etc.

McEwen, Robert W. "The North Central 
Association's 1943 Survey of College and University Libraries," College \& $R e$ search Libraries 4:253-56 (June 1943).

“. .. The North Central Association took an important step some few years ago in deciding to base its accreditation on the acknowledged aims and curricular objectives of each institution.

“. . . The assumption of the 1934 North Central checklist that there would be a high correlation between holdings in the reference collection and library book holdings in general was statistically established."

Mohrhardt and Shaw lists, Shaw supplement, Mudge-Winchell lists, and Lyle list of periodicals were used.

McGrath, W. E.; Huntsinger, R. C.; and Barber, G. R. "An Allocation Formula Derived from a Factor Analysis of Academic Departments," College \& Research Libraries 30:51-62 (January 1969).

Tallied books published in the U.S.-derived from several American book publishing records.

Maizell, R. E. "Standards for Measuring the Effectiveness of Technical Library Performance," IRE Transactions on Engineering Management EM7:69-72 (June 1960).

Quality of collection: compare with published lists of key literature or citations in library's most used journals. Note records on library's ability to fill users' requests.

Meder, Albert E. "Accrediting Agencies and the Standards," Drexel Library Quarterly 2:213-19 (July 1966).

"In summary, the influence of professional librarianship upon college evaluation has been more effective and more pervasive through creation of the Standards than would have been possible through direct accreditation of college libraries by the profession. In a sense, professional librarianship has found its life by losing it and achieved true success by emphasizing the spirit of quality and service rather than the letter of quantitative measures."
Middle States Association of Colleges and Secondary Schools. Commission on Institutions of Higher Education. Evaluating the Library: Suggestions for the Use of Faculties and Evaluation Teams. The Association, 1957. 2p.

Evaluation should be made in relation to the institution's own mission and requirements. These facts having been established it should be determined to what extent the necessary resources are available and accessible.

Middle States Association of Colleges and Secondary Schools. Commission on Institutions of Higher Learning. "What to Consider in Evaluating the Library," Library Journal 83:1656-58 (1 June 1958).

A library evaluation prerequisite is an exact description of the institution's mission and the means by which the institution proposes to fulfill it. Use of the library by students is the ultimate test of its effectiveness. Questions for evaluating the library include the following.

Is the library collection (a) broad, varied, authoritative, up-to-date; (b) supplemented by source, monographic, and periodical material for advanced study/research; (c) sufficient for specialized and technical fields offered by the institution; (d) being expanded so as to fill in gaps; (e) weeded efficiently to keep it solid and current; (f) supplemented but not replaced by interlibrary loans; (g) such as to facilitate advanced study and research by the faculty; and (h) buying enough new books to keep abreast of advances in the fields of instruction and research of the institution.

Miles, Ida R. "Scientific Collections in the University of Tennessee-Oak Ridge Area," College \& Research Libraries 19: 19:223-26 (May 1958).

Evaluation based on C. H. Brown's Scientific Serials, 1956.

Moon, E. E. "Standards for Everything," Library Journal 90:209 (15 January 1965).

Mr. Moon finds the "Objectives and Standards for Special Libraries" a state- 
ment of generalities and a presentation of the qualities sought by the special library.

Morris, Junius Hugh. "The Feasibility of Using Criteria Book Lists to Evaluate Junior College Library Holdings," Dissertation Abstracts 29:621A (August 1968).

Random samples of from 49 to 64 books were selected from each of the following lists: (1) Hilary J. Deason, "The AAAS Science Book List for Young Adults"; (2) Frank J. Bertalan, "The Junior College Library Collection"; (3) Melvin J. Voight and J. H. Treyz, "Books for College Libraries"; (4) Warren B. Kuhn, "The Julian Street Library"; (5) Richard J. Lietz and W. A. Pease, "The Opening Day Collection, Choice, Special Supplement (1967)...."

Norris, Elizabeth D. "Establishing Standards," Special Libraries 51:229-31 (May 1960).

The base for a set of standards for a special library is the organization's objectives. Quantitative standards involve the number of books, the extent of subject resources, and tools of bibliographic control.

"Objectives and Standards for Special Libraries," Special Libraries 55:672-80 (December 1964).

The following objectives and standards pertain to the book collection: (1) The subject coverage of the special library's collection should be intensive and extensive enough to meet the current and anticipated requirements of its clientele; (2) the size depends on the amount of available material that is pertinent to the organization's needs; and (3) acquisition policies should be established within the framework of the library's stated objectives.

"Optimum Size of Libraries: A Symposium . . . Four Papers . . . Presented at the General Session of the ACRL, 1949 Annual A.L.A. Conference, Atlantic City, Oct. 6, 1949," College \& Research Libraries 11:137-49 (April 1950).

For analysis of contents, see Gosnell, C. F.- "Systematic Weeding"; McCrum, B. P.-"Book Selection in Relation to the
Optimum Size of a College Library"; Webb, Helmer - "The Optimum Size of the College Library"; Rogers, R. D.--"Regional Depository Libraries and the Problem of Optimum Size of College and University Libraries."

Orne, Jerrold. "Place of the Library in the Evaluation of Graduate Work," College \& Research Libraries 30:25-31 (January 1969).

Abstract: "Traditional, time-honored methods of evaluating the adequacy of academic libraries for graduate work are no longer adequate in themselves. Rising numbers of students, changing degree programs, and advancing costs are rendering traditional evaluation methods less and less adequate. Greater attention should be devoted to the assessment of research collections in the region, to pondering new kinds of library plant needs, to rethinking the use of library personnel, to seeking new systems for funding library operations, and to articulating librarians more completely into the university community."

Orne, Jerrold. "Renaissance or Oblivion, or, Where Away Our Great Research Libraries?" Rub-Off 19:1-4 (MarchApril 1968).

A general article which discusses the difficulty of making comparison when statistical measures vary. Some libraries report microforms as books, or uncataloged material as part of the library. There is a compulsion to use standard lists and specific size indicators.

Pargellis, Stanley. "Building a Research Library," College \& Research Libraries 5:110-14 (March 1944).

The author presents a case for selectivity in its acquisition policy in the belief that the great research library should deliberately set out to acquire the best books in any field.

Parker, W. W. "College Library Standards and the Future," College \& Research Libraries 19:357-64 (September 1958). "The chief concern of the [college] librarian ought to be the book collection." But the author goes on to say that "A col- 
lege library is selective and a good college library must choose at both ends, buying the essential new books and weeding the surplus and less useful material." $\mathrm{He}$ recommends advice of specialists and comparison with standard, authoritative lists.

Patterson, Marianne A. "Some Practical Aspects of Medical Society Library Operation: A Symposium. Preserve or Discard? A Problem in Librarianship." Medical Library Association, Bulletin 46: 45-49 (January 1958).

Many medical libraries ignore the fact that there are national libraries and comprehensive collections which preserve everything. It is a false standard which evaluates a library according to the number of volumes; the quality of the collection and service would be wiser criteria.

Pennsylvania. University. Library. Changing Patterns of Scholarship and the Future of Research Libraries: A Symposium; ed. by R. Hirsch. Philadelphia, University of Pennsylvania Press, 1951. 133p.

R. E. Ellsworth and V. M. Clapp discuss comprehensiveness versus selectivity in building collections. Both consider the massiveness of published materials and the need for national and regional bibliographic control and book handling.

Piternick, George. "Library Growth and Academic Quality," College \& $R e$ search Libraries 24:223-29 (May 1963).

The author maintains that "the absolute size of a university library's holdings and the absolute size of its yearly gross increments, and not its current growth rate, are the best measures of its quality...."

Randall, G. E. "Special Library Standards, Statistics, and Performance Evaluation," Special Libraries 56:379-84 (July-August 1965).

Contains a one-page section on "special library collections." Included is this quote from SLA Standards: "The collection is intensive and extensive enough to meet both current and anticipated literature needs. The size of the collection depends on what is available in the subject area."

Raney, M. Llewellyn. The University Libraries. Chicago, University of Chicago Press, 1933. (University of Chicago Survey, VII.)

More than 400 lists and bibliographies were used for checking subject collections.

Reichard, E. W. and Orsagh, T. J. "Holdings and Expenditures of U.S. Academic Libraries: An Evaluative Technique," College \& Research Libraries 27:478-87 (November 1966).

Acquisitions expenditures are examined relative to the number of students and faculty by the use of random sampling.

"Report on Conference [to Explore Some Current and Anticipated Problems in the Building of Book Collections in Libraries, Held in Chicago April 20-21]," Library Journal 84:1765-67 (1 June 1969). A discussion of the value and use of basic lists.

Rider, Fremont. "The Scholar and the Future of the Research Library," New York: Hadham Press, 1944. 236p.

"Research libraries are primarily, the stored-up knowledge of the race, warehouses of fact and surmise, in all their forms and infinitely remote ramifications, the raw material from which our humanists and our scientists are going to develop later new facts and fresh surmises. Research materials are in a sense the building blocks of civilization, and the storage element in the function of the research library-just the sheer holding of book and periodical materials, not for any immediate use at all, but for some possible, and possibly very remote, future use-is an extremely important, but not always very well understood part of that function."

Rogers, Rutherford D. "Regional Depository Libraries and the Problem of Optimum Size of College and University Libraries," College \& Research Libraries 11:147-49 (April 1950).

Little-used materials of research significance can be stored at the regional de- 
pository library, still available for those engaged in research, but also providing a solution to the overgrowth problem.

\section{Russel, John H. "Library Self-Survey," College \& Research Libraries 17:127- 31 (March 1956).}

An evaluation of the library of an educational institution is part of a check on the effectiveness of the total institution. The library facilities must serve the mission of the institution.

Samore, Theodore. "Current Condition of American Academic Libraries," Higher Education 20:7-10 (December 1963).

In trying to determine whether a college library is good or bad the author says: "It can, however, judge for itself the adequacy of its own library by comparing its resources with certain quantitative standards recommended by the American Library Association. . . . Both documents stress the point that 'The standards must always be interpreted in the light of the aims and needs of the institution of which the library is a part."

Sawyer, Rollin A. "Book Selection in the Reference Department of the New York Public Library," College \& Research Libraries 6:20-22 (December 1944).

The author refers to the New York Public Library as "one of the few great research libraries of the world." He says further that "The ideal objective of such a library is a complete record of human thought, emotion and action. Its collections should be developed without distinction as to language, date, place, and form of publication. In short, it should have everything. ..."

Schnorrenberg, John W. "Holdings of Art Books in Southeastern Libraries: A Survey and Report," Southeastern Librarian 15:186-97 (Winter 1965).

A college professor tried to find out how Southeastern libraries approach national standards. By means of a questionnaire he tried to find out the size of the library, the amount spent on art books, the number of art students and faculty, and the degree of specialization in the collection. Libraries were asked to check a list of series, serials, and individual titles.

Sewell, P. H. "The Evaluation of Library Services in Depth," UNESCO Bulletin for Libraries 22:274-80 (November-December 1968).

There is a section on the evaluation of the book stock. Of this the author says: "There are advantages in expressing standards of bookstock in terms of annual additions to stock rather than total stock as this helps to indicate the relevance of what is being provided and whether it is up to date."

Because of changing monetary values "standards are better expressed as the number of volumes added rather than in terms of expenditure."

Shera, Jesse H. "Standard Lists-An Unstandardized View," Wilson Library Bulletin 41:615, 630 (February 1967).

While admitting the merits of many "standard" lists, the author thinks librarians have the responsibility for selection and that it is a part of a librarian's professionalism.

Shipman, Joseph C. "'Optimum Size' and the Large Science Research Library," College \& Research Libraries 27:354-57, 392 (September 1966).

Among "devices" used in determination of optimum size are: (1) Establishment of restrictive limits of subject selection; (2) the use of literature citation counts for determining most-used serial titles, as well as for most-used foreign language titles; (3) dependence upon neighboring libraries for particular areas of subject strength, and for breadth of coverage; (4) extensive use of interlibrary loans; (5) discriminating weeding; and (6) selective microfilming and purchase of microfilm.

Shores, Louis. "Evaluating Library Service to Higher Education," College \& $R e$ search Libraries 2:211-15, 236 (June 1941).

The quantitative standards were based on the number of students, budget, cur- 
riculum offered, and degrees offered. The qualitative standards were based on sampling from reference and periodical lists.

Simpson, Mary Lofton. "Experiment in Acquisition with the Lamont Library List," College \& Research Libraries 15:430-33 (October 1954).

The mission of the library of the Air University is to support the courses of instruction as well as a research program. In 1942 , it undertook a review of its book collection on an undergraduate level using the Lamont list. It was not the intent to imitate the Lamont holdings "but to employ the list of basic titles from a selective viewpoint."

Snyder, Monroe B. "An Examination of Methods Used in a Study of DecisionMaking," ALA Bulletin 61:1319-23 (December 1967).

This is a description of the methods used to collect empirical data on the selection of science library materials. The project had two major objectives: (1) to describe the selection process as it existed; and (2) to provide practical guidelines designed to assist decision-makers in selection.

Special Libraries Association. "Appraisals of 'Objectives and Standards for Special Libraries," Special Libraries 56: 197-201 (March 1965).

At the time the Standards were published a number of library consultants, a library school dean and professor, an administrator in industry, a library specialist in the U.S. Office of Education, and practicing special librarians were asked to submit their frank opinions.

Stieg, Lewis. "A Technique for Evaluating the College Library Book Collection," Library Quarterly 13:34-44 (January 1943).

"The technique described in this study for evaluating the college library book collection is based upon the use made of it. Two of the more important assumptions involved are: (1) the adequacy of the book collection is directly related to its use by students and faculty; (2) the circu- lation records of books withdrawn for home use give a reasonably representative picture of the use made of the library. ..."

Subbarao, M. Suseela. "Place of Library Resources in Doctoral Programs," College of Research Libraries 29:424-30 (September 1968).

Abstract: "This paper supplements an earlier paper by .Robert B. Downs on doctoral programs and library resources. While the factors involved in successfully implementing a doctoral program are many and complex, to carry out such a program in a variety of fields, it appears that there should be at least three thousand current periodicals (and five hundred thousand volumes, as Dr. Downs states). Even with the best library resources, one cannot generally hope to produce more than one doctorate out of every ten graduate students enrolled in any one year, as figures in this paper indicate."

Tanis, N. E. and Jacobs, K. J. "Strengthening the College Library, Drexel Library Quarterly 2:276-91 (July 1966).

"A sketch of the library evaluation and the series of questions that the Committee constructed at the Henry Ford Community College may be helpful to other junior colleges interested in implementing the new Standards."

Tauber, Maurice F.; Cook, C. Donald; and Logsden, Richard H. The Columbia University Libraries. A Report on Present and Future Needs Prepared for the President's Committee on the Educational Future of the University. New York: Columbia University Press, 1958. 320p.

Evaluation of the library resources may be approached in the following ways: (1) checking resources against bibliographies in different subject fields; (2) seeking faculty opinion on collections; (3) examining users' difficulties in obtaining materials needed for course work and research; and (4) measuring the collection against the holdings of other research libraries in the country.

Tauber, Maurice F. “Columbia University 
Libraries Self-Study," College \& $R e$ search Libraries 19:277-82 (July 1958).

Concerning the library resources, the author says: ". . . How does one measure the resources of a library? In surveys of libraries which have been made in American university libraries, there has been a common pattern of evaluating holdings through such measurements as (1) checking the resources against bibliographies in separate subject fields, (2) seeking faculty opinions on the strengths and limitations of collections, (3) examining users' difficulties in obtaining materials needed for course work and research, and (4) measuring the collections against the holdings of other research libraries in the country. ..."

Tauber, Maurice F. and Stephens, Irlene R., eds. Library Surveys. New York: Columbia University Press, 1967. 286p. (Columbia University Studies in Library Science, No. 16.)

A comprehensive treatment of surveys with extensive bibliographies. The papers by M. M. Gormley on Academic Libraries and by E. E. Williams on Surveying Library Collections are of special significance.

Tauber, Maurice F. "Survey Methods in Approaching Library Problems," Library Trends 13:15-30 (July 1964).

Surveying, whether by a single specialist, a team of specialists, or self-survey, is given broad coverage. On evaluation of collections, mention is made of the use of checklists and sampling, special analysis by language and subject, and lack of uniformity in reporting statistics. Bibliography at end.

Thompson, Lawrence S. "Consult the Scholars," Library Journal 92:1804 (1 May 1967).

The author thinks the competent scholar is the one qualified to select and build a research library.

Thompson, Lawrence S. "The Dogma of Book Selection in University Libraries,"

College \& Research Libraries 21:441-45 (November 1960).

"It seems to be generally recognized that if a library is to be a research library in the best sense, it must be comprehensive in its fields of emphasis, including good, bad, and indifferent...."

Webb, Helmer. "The Optimum Size of the College Library," College \& Research Libraries 11:143-47 (April 1950).

The author advocates a cut in size of such libraries, with constant weeding and warehouse storage within eight hours' distance.

Weber, D. C. "Criteria for Evaluating a College Library," Association of American Colleges, Bulletin 43:629-33 (December 1957).

One of the three major aspects of evaluating college libraries relates to the collection. There should be a sufficient quantity of the books required and suggested by the faculty for the subjects taught.

Willging, Eugene P. "Catholic College and University Library: A Second Survey," Catholic Educational Review 51:577-91 (November 1953).

This second survey checked quality against "Books for Catholic Colleges," considered microcard and film, interlibrary loan, etc.

Williams, Edwin E. "Research Library Acquisitions from Eight Countries," $\mathrm{Li}$ brary Quarterly 15:313-23 (October 1945).

The purpose of the study was to examine resources of the country as a whole, not to compare individual collections. The technique followed was to prepare a list of 111 subjects for checking against the best available bibliography.

Williams, Edwin E. "Surveying Library Collections," in Maurice F. Tauber and Irlene R. Stephens, eds., Library Surveys, p.23-45. New York: Columbia University Press, 1967.

While quantitative statistics on collections are available they are often unreliable. The quality of a collection is best determined by comparison with lists and special bibliographies.

Wilson, Louis R. and Tauber, Maurice F. 
The University Library: The Organization, Administration, and Functions of Academic Libraries. New York: Columbia University Press, 1956. 2d ed. 641p.

Principal method of evaluating libraries in surveys has been by comparison of various kinds: (1) Present conditions of library with those of past years. Helpful in revealing long-term trends for collections, books use, etc.; (2) the library in relation to comparable aspects of the university as a whole; (3) comparison with libraries of similar institutions. Need for precise definitions and consistent methods of collecting data to be certain data are comparable; (4) use of external standards. Generally products and materials to which standards may be applied are intellectual and not mathematically or quantitatively definable. Main difficulty in developing standards is that libraries vary in their objectives.

Wilson, Louis R. "The University Library Survey: Its Results," College \& Research Libraries 8:368-75 (July 1947).

This is a history of the many surveys including information on the procedure employed by each. There were two types of surveys, limited and general, depending on the purpose for which the survey was conducted. When collections were examined in detail it was for the purpose of compiling desiderata lists or guides for rounding out the collection, or providing a checklist of existing resources. 